\title{
Technical and Vocational Education in the Context of Reindustrialization. The Case of Romania
}

\author{
P. Dobrescu*, L. Radu* \\ *National University of Political Studies and Public Administration, Bucharest, Romania
}

\begin{abstract}
This paper aims to analyse the feasibility of a vocational and technical education campus in Central Romania (Braşov County). We discuss the necessity for such an initiative in the context of the EU reindustrialization strategies. There is a strong correlation and a causal relationship between economic growth, reindustrialization and employment (especially youth employment). In many EU countries, youth unemployment rate is increasing, despite the fact many organizations report that they lack properly trained workforce. Definitely, skills needed to enter the labour market are diversifying; some areas are oversaturated with overqualified specialists, while others remain weak in terms of welltrained workforce. This phenomenon signals the gap between the demand for skills, on the one hand, and the skills supply, on the other hand. This paper addresses this gap by proposing a comprehensive plan for reviving technical and vocational education in Central Romania, while taking a close look to educational (i.e. distribution of seats available at high schools, depending on the branch organization of the secondary education), economic (i.e. economic crises, industrialization of community building countries) and social (i.e. unemployment rate, social groups and structures) factors.
\end{abstract}

Keywords: technical and vocational education, reindustrialization, skills, unemployment

\section{Introduction}

The post crisis world has undergone structural changes. It has changed especially when referring to developed countries, which have been most affected by the economic earthquake that started in 2008. These countries have not reached the GDP levels or the development rate they had had before the crisis. Financial and economic tensions prevent many countries from attaining a real economic recovery, which translates into modest growth rates, which could hardly be situated between 1 and 2 percent. For instance, estimations on EU growth are around one percent. This is below of what Paul Krugman, winner of the Nobel Prize, calls technical recovery. Economic revival is only possible when actual growth exceeds two percent. USA is closer than the EU to this target.

The crisis, which has started as a financial crisis has gradually transformed into an economic crisis. The region that was most severely affected by the crisis in the developed world is Europe. According to The Economist, Europe's economic situation is "the main economic problem of the world." The Union still accounts for almost one fifth of the world's output; however, EU's growth trend is going downwards, one of the explanations being what the above cited magazine called "its self-destructive behaviour."

There is a whole debate about the factors that have led the European Union to be in such a distress. For this paper we only focus on two key explanations. The first one is that EU is an unfinished project, stuck between the sovereignty ideal, which emphasizes the state and its powers - on the one hand, and the federalist perspective, which, by contrast, emphasizes the importance of supranational structures - on the other one. EU is somehow caught between these two perspectives, which hinder effective strategic decision-making. According to David Marquand, "the new, continent-wide Union of the 2000s, with its twenty-seven member-states, its 500 million citizens, and its Europeanized currency and the Central Bank, was still trapped in the old halfway house between con-federalism and federalism. The foundations were patently shifting under 
the weight they now had to carry; there were cracks in the ceiling and loose slates in the roof" (2011, p. xi).

The second explanation is linked to the emergence of the so-called "financial periphery", involving a gap between Northern Europe and Southern Europe. This raises the question of economic and psychological fragmentation of the Union. Southern Member-States have accumulated more debt and saw looming unemployment rates, while needing considerable financial aid.

The economic strength of a state has two main sources: the workforce (population size) and the productivity rate. EU has an important vulnerability - as compared not only to emerging countries, but also to developed countries (e.g. USA): shrinking demography and accelerated aging.

\section{EU's Development Gaps and Reindustrialization}

Economic advancement and GDP growth are essential ingredients of development, though not the only ones. Development is an economic phenomenon as much as it is a social one, involving poverty, unemployment, and inequality reduction. Therefore, it should be conceived as a multidimensional process that implies the reorganisation and reorientation of the entire economic and social system. In addition to the improvement of income and productivity, development implies, typically, radical changes in the institutional, social and administrative structures. Development also implies changes in peoples' attitudes and, in many cases, even in their habits and beliefs - therefore, it implies cultural changes (Adelman, 1999). In EU, debates on development are strongly focused on reindustrialisation. Currently, industry sectors generate $16 \%$ of the EU's GDP. According to the 2020 Horizon Strategy, industry should account for $20 \%$ of the GDP. The four pillars taken into account at the level of reindustrialisation are: investments in innovation, better market conditions, access to capital, and skills improvement. Therefore, education should match the development needs.

The engine of development is knowledge, under its different forms - education, innovation, academic research and industrial research, personal improvement. We might rightfully state that knowledge is the engine of development - here, knowledge takes various shapes, such as education, academic and industry research, personal development - only to name a few. "Development requires closing the gap not only in “objects”, in human and physical capital, but also in knowledge. Knowledge and capital are in fact complements: improved knowledge enhances the return to capital, while additional capital provides the opportunity to make use of recently acquired knowledge. Incorporating knowledge into the development strategy requires creating capacities to absorb and adapt knowledge (through investments in human capital and in research institutions), investing in technologies to facilitate the dissemination of knowledge, and creating knowledge locally." (Stiglitz, 1998) Or, in the word of Th. Piketty (2014), "the main forces for convergence are the diffusion of knowledge and investment in training and skills." 


\section{Vocational and Technical Education in Romania}

\section{Background}

After a strong contraction in 2009, the Romanian economy has begun to recover; however, in Romania there are important disparities between the strongly urbanised areas - that have become growth poles - and rural and semi-urban areas - strongly affected by poverty. The most recent report of the European Commission regarding the economic and social cohesion reveals a deep gap between the Bucharest-Ilfov area (that has a GDP of $120 \%$ of the EU average) and the North-East region (that has a GDP of $24 \%$ of the EU average, being one of the poorest regions of the EU).

An important key to boosting development is reindustrialisation, a phenomenon that is starting to become more and more visible in several regions - including Central Romania. Brașov county is situated at the very centre of Romania, being subject to a steadily intensifying reindustrialisation process. Currently, the number of technical and professional education units in Brașov county $(49,4 \%)$ is below national average (54,5\%) and one of the lowest in Central Romania. In Brașov county, the number of students enrolled in highschools is constantly decreasing: in 2007 there were reported 20727 highschool students, as compared to only 17518 in 2014 (according to the data provided by the Ministry of National Education). While the decrease of the number of students in highschools is a consequence of the demographic decline, it is also an effect of the fact that preuniversity education is not properly fit to the local development trends. This is illustrated by the the increasing number of students who choose to attend technical and vocational schools.

\section{Objectives}

The educational campus in Brassov county has the general objective to create a pole of excellence for training and qualifying workforce for the most representative industry sectors in Central Romania.

The general objective will be made operational through several specific objectives, as follows: to build the infastructure of the vocational and technical campus; to recruit the teaching staff; to certify the training modules/qualifications; to organize internships/apprenticeships in various companies; to provide the specialists with career counseling services; to promote the educational campus and to position it as a regional pole of excelence in vocational and technical training.

\section{SWOT Analysis}

A SWOT analysis (Table 1) was prepared in order to identify the best options for creating the educational campus:

Table 1. SWOT Analysis for building a vocational and technical training campus in Brasov County

\begin{tabular}{|l|l|}
\hline \multicolumn{1}{|c|}{ Strengths } & \multicolumn{1}{c|}{$\begin{array}{c}\text { Weaknesses } \\
\text { - The industrial tradition of } \\
\text { Brașov County }\end{array}$} \\
- $\begin{array}{l}\text { High number of companies } \\
\text { (large companies and SMEs) }\end{array}$ & $\begin{array}{l}\text { Lack of experience in managing } \\
\text { a program of similar complexity, } \\
\text { with various activities } \\
\text { (construction and office }\end{array}$ \\
\hline
\end{tabular}




\begin{tabular}{|c|c|}
\hline $\begin{array}{l}\text { active in the industrial } \\
\text { production in Brașov county } \\
\text { - } \text { Interest of the Brașov County } \\
\text { Council for industrial } \\
\text { development } \\
\text { - } \quad \text { The attractiveness of county / } \\
\text { city of Braşov for potential } \\
\text { learners } \\
\text { - } \quad \text { Industrial parks and business } \\
\text { incubators } \\
\text { - Existing facilities which may be } \\
\text { subject to expansion and } \\
\text { modernization }\end{array}$ & $\begin{array}{l}\text { equipment, construction and } \\
\text { equipping workshops for } \\
\text { internship / apprenticeship } \\
\text { training, digital content for e- } \\
\text { learning, ongoing internship / } \\
\text { apprenticeship communication } \\
\text { and awareness) } \\
\text { - Limited financial resources in } \\
\text { public administration and } \\
\text { reduced availability of private } \\
\text { funding for such a long-term } \\
\text { investment }\end{array}$ \\
\hline $\begin{array}{l}\text { Opportunities } \\
\text { - } \\
\text { European policies, strategies and } \\
\text { qualified labour force, reducing } \\
\text { unemployment among young } \\
\text { people, supporting } \\
\text { disadvantaged groups etc. } \\
\text { - } \text { Harmonization of EU policies } \\
\text { and strategies and those existing } \\
\text { at a national level } \\
\text { The existence, in the Ministry of } \\
\text { National Education, of policies } \\
\text { to support vocational and } \\
\text { professional high schools } \\
\text { Structural Funds available for } \\
\text { this kind of program (creating / } \\
\text { upgrading educational } \\
\text { infrastructure, IT\&C } \\
\text { infrastructure and the creation of } \\
\text { digital content for e-learning, } \\
\text { training, internships and } \\
\text { apprenticeship, developing } \\
\text { infrastructure for SMEs to host } \\
\text { internships and apprenticeships); } \\
\text { Scalability: possibility of } \\
\text { extending the idea of creating a } \\
\text { vocational campus or steps to be } \\
\text { followed in other regions of the } \\
\text { country. }\end{array}$ & $\begin{array}{l}\text { Threats } \\
\text { - } \quad \text { Low popularity of vocational } \\
\text { and technical careers among } \\
\text { young people; } \\
\text { - } \quad \text { Workforce migration to more } \\
\text { developed countries (e.g. } \\
\text { Germany); } \\
\text { - The perception that the technical } \\
\text { education / vocational education } \\
\text { is a second-hand education } \\
\text { (perception among young } \\
\text { people, parents, employers); } \\
\text { - Few qualified trainers/teachers; } \\
\text { - Low involvement of companies } \\
\text { in the construction of the campus } \\
\text { workshops or hosting internships } \\
\text { / apprenticeships in their own } \\
\text { premises; } \\
\text { Co-funding and cash-flow for } \\
\text { EU-funded projects; } \\
\text { Excessive bureaucracy in the } \\
\text { implementation of publicly } \\
\text { funded projects; } \\
\text { Delays in the reimbursement of } \\
\text { expenses incurred in the project; } \\
\text { Social complexity of creating } \\
\text { campus vocational program } \\
\text { (different and interdependent } \\
\text { stakeholders - central and local } \\
\text { government, private } \\
\text { environment, schools, chamber } \\
\text { of commerce etc.) } \\
\text { Fluctuating regulatory } \\
\text { framework; } \\
\text { Identification of optimal legal } \\
\text { form of legal entity that will }\end{array}$ \\
\hline
\end{tabular}




\section{Key Phases}

The vocational and technical training campus is a complex program consisting of several projects - each with specific funding sources and timeframe for preparation and implementation. In what follows, we present both project ideas and potential funding sources for the construction and operation of the campus. It will be a complex program (Table 2) consisting of several integrated projects that can be financed from several sources of financing, such as:

Table 2. Program for building a vocational and technical training campus in Brasov County

\begin{tabular}{|c|c|}
\hline $\begin{array}{l}\text { Operational } \\
\text { Programme }\end{array}$ & Projects / specific actions \\
\hline \multirow{2}{*}{$\begin{array}{l}\text { Sectorial } \\
\text { Operational } \\
\text { Programme for } \\
\text { Economic } \\
\text { Competitiveness }\end{array}$} & $\begin{array}{l}\text { Building the IT campus infrastructure (computer labs, } \\
\text { networking, Internet connection) }\end{array}$ \\
\hline & $\begin{array}{l}\text { Creating the e-learning platform of the campus (acquisition and } \\
\text { tailoring of a professional platform for e-learning, development of } \\
\text { digital content, teacher training / platform users, the acquisition of } \\
\text { electronic resources for e-library) }\end{array}$ \\
\hline \multirow{3}{*}{$\begin{array}{l}\text { Sectorial } \\
\text { Operational } \\
\text { Programme } \\
\text { Human Capital }\end{array}$} & $\begin{array}{l}\text { Designing of the curricula and preparation of files for validation } \\
\text { of qualifications offered by the campus in accordance with the } \\
\text { National Qualifications Register (ANC) }\end{array}$ \\
\hline & $\begin{array}{l}\text { Realization of pilot training programs / qualifications for different } \\
\text { categories of the target group, especially for disadvantaged } \\
\text { groups (unemployed, especially young people looking for a job, } \\
\text { Roma people) }\end{array}$ \\
\hline & $\begin{array}{l}\text { Integration into the labour market: } \\
\text { - The development of apprenticeship programs. } \\
\text { - } \text { Counselling for socio-professional integration. } \\
\text { (teachers, trainers, administrative staff) } \\
\text { - Studies / analyses / forecasts made in Brașov county and } \\
\text { neighbouring counties on the evolution of the labour } \\
\text { market, the need for skills, training and retraining, skills } \\
\text { and emerging qualifications } \\
\text { - Funding internships and apprenticeships. }\end{array}$ \\
\hline $\begin{array}{l}\text { Regional } \\
\text { Operational } \\
\text { Programme }\end{array}$ & $\begin{array}{l}\text { Campus infrastructure - options: } \\
\text { - Identification of a vocational school that can be } \\
\text { rehabilitated / upgraded/redesigned. } \\
\text { - Building a greenfield campus, including workshops, } \\
\text { internships internship spaces and apprenticeship, } \\
\text { accommodation for students. }\end{array}$ \\
\hline
\end{tabular}


Partnering with SMEs relevant to the campus priorities.

Creating business incubators for graduates.

\section{Conclusions}

Romania has to enroll in the European race for competitiveness and reindustrialization. This requires two interrelated ingredients: a healthy industry and a properly trained workforce. According to the latest Country Report, "Romania has taken steps in addressing youth unemployment [...], but the high number of young people who are not in education, employment or training remains a challenge.” (2015, p. 61). Thus, one of Romania's priorities should be to create the proper grounds for educating a qualified work force fit for the needs of today's and tomorrow's society. This would translate not only into economic development, but also into social well-being. Our case study is intended to help accelerate such a positive evolution. Braşov County holds an important stake in the development of the Romanian industry and could constitute a good starting point for improving Romania's economic performance. It could also constitute a best practice for other emerging regions, which would be able to reach their full potential by expanding education opportunities and, consequently, providing feasible career paths for youth.

\section{References}

Adelman, I. (1999). Fallacies in Development Theory and Their Implications for Policy, CUDARE Working Paper Series nr. 887, University of California at Berkeley, Department of Agricultural and Resource Economics and Policy.

Marquand, D. (2011). The End of the West. The Once and Future Europe. UK: Princeton University Press.

European Commission. (2015). Country Report Romania 2015 Including an In-Depth Review on the prevention and correction of macroeconomic imbalances. Retrieved from http://ec.europa.eu/europe2020/pdf/csr2015/cr2015_romania_en.pdf on 2015 April 12.

European Commission. (2010). Europe 2020. Retrieved from http://eurlex.europa.eu/LexUriServ/LexUriServ.do?uri=COM:2010:2020:FIN:RO:PDF on 2015 April 21.

Piketty, T. (2014). Capital in the Twenty-First Century, Harvard: Harvard University Press.

Stiglitz, J. (1998). Towards a New Paradigm for Development: Strategies, Policies and Processes. Lecture given as the 1998 Prebisch Lecture at UNCTAD, Geneva, October 19. 